Abstracta Iranica

Revue bibliographique pour le domaine irano-aryen

Volume 34-35-36 | 2017

Comptes rendus des publications de 2011-2013

\title{
Edward DĄbrowa. Hellenistic Elements in the Parthian Kingship: The Numismatic Portrait and Titolature
}

\section{Fabrizio Sinisi}

\section{(2) OpenEdition}

\section{Journals}

Electronic version

URL: http://journals.openedition.org/abstractairanica/42345

DOI: 10.4000/abstractairanica.42345

ISSN: 1961-960X

Publisher:

CNRS (UMR 7528 Mondes iraniens et indiens), Éditions de l'IFRI

Electronic reference

Fabrizio Sinisi, «Edward Dąbrowa. Hellenistic Elements in the Parthian Kingship: The Numismatic Portrait and Titolature », Abstracta Iranica [Online], Volume 34-35-36 | 2017, document 56, Online since 30 July 2017, connection on 02 October 2020. URL : http://journals.openedition.org/abstractairanica/42345 ; DOI : https://doi.org/10.4000/abstractairanica.42345

This text was automatically generated on 2 October 2020.

Tous droits réservés 


\title{
Edward DĄbrowa. Hellenistic Elements in the Parthian Kingship: The Numismatic Portrait and Titolature
}

\author{
Fabrizio Sinisi
}

\section{REFERENCES}

Edward DĄbrowa. « Hellenistic Elements in the Parthian Kingship: The Numismatic Portrait and Titolature », in: E. DĄbrowa, ed., Studia Graeco-Parthica. Political and Cultural Relations between Greeks and Parthians. Wiesbaden, 2011, p. 143-151. (Philippika, 49)

Arsacid numismatic iconography and titolature show that the Parthians deliberately followed Hellenistic patterns to achieve political and propaganda aims focused on bolstering the ideological foundations of their kingship. Royal iconography shows the Hellenisation of the portrait under Mithradates I, while the Parthian archer of the drachm reverses was inspired by the Seleucid Apollo on omphalos. The coin titolature, much richer in comparison to Seleucid patterns, is divided in titles referring to the kings' political and religious status, royal victories, personal qualities, family links.

\section{AUTHORS}

FABRIZIO SINISI

Österreichische Akademie der Wissenschaften 